\title{
ELECTRON MICROSCOPIC RADIOAUTOGRAPHY USING A COMBINATION OF PHENIDON DEVELOPER AND DOMESTIC EMULSION
}

\author{
Fusayoshi MURATA, Keizo YOSHIDA*, Shinichi OHNO* \\ and Tetsuji NAGATA* \\ Department of Anatomy, Kagoshima University School of Medicine, \\ Kagoshima 890 and Shinshu Liniversity School of Medicine,* \\ Matsumoto 390
}

Received for publication May 2, 1979 and in revised form June 11, 1979

\begin{abstract}
A routine procedure for electron microscopic radioautography in combination with phenidon developer and the domestic emulsion, Sakura NR-H2, was developed. Good stable radioautograms have not been obtained by simply developing the emulsion coated grids with phenidon developer at any temperature, but the development of these grids at $18^{\circ} \mathrm{C}$ for $1 \mathrm{~min}$ after 30-45 sec gold latensification in freshly prepared gold thiocyanate gives satisfactory results. Some electron microscopic radioautograms developed by this method are presented. The addition of the anionic surfactant, dioctyl sodium sulphosuccinate, to the emulsion was found to be very effective not only for preventing the burst of emulsion but also in obtaining a uniform spread of the emulsion for the wire loop method. Radioautograms obtained with this method are suitable for quantitative electron microscopic radioautographic studies. Details of this method are introduced.
\end{abstract}

It is generally accepted that there are many difficulties in the study of electron microscopic radioautography. Among them, the efficiency of the development is the most important factor affecting the grain size, the resolution and the background. In 1966, Lettré and Paweletz (14) reported a recipe for phenidon (1-phenyl 3-pyrazolidone) developer. This recipe was not widely used as a developer for electron microscopic radioautography for several years. From the end of the last decade, Young and his cowerkers $(1,2,25,26)$ began to report many electron microscopic radioautograms using this developer. Now, this method is widely used as a developer for electron microscopic radioautography. The phenidon developer yields approximately uniform dot-like silver grains easy to identify, and for this reason, this developer is widely used for quantitative electron microscopic radioautographic study. At present, there are three popular nuclear emulsions available for electron microscopic radioautography: Ilford L4, Sakura NR-H2 and Kodak NTE. However, a survey of the literature shows that almost all researchers using this developing method used If lord L4 as a nuclear emulsion $(1,2,25,26)$. In this country, Hirosawa and Yamada (9, 10), Hama and Hirosawa (6), Ishiko (12), Ichikawa and Ichikawa (11) reported electron microscopic radioautographic studies using this developer in combination with Ilford L4 nuclear emulsion. 
On the other hand, Sakura NR-H2 is a product of Japan and is commercially available in this country. The cost of Sakura NR-H2 is about one fourth that of Ilford L4 in Japan. The average size of a crystal of silver bromide of Iflord L4 is $0.12 \mu \mathrm{m}$, while that of Sakura NR-H2 is $0.07 \mu \mathrm{m}$ (15). Generally, the smaller the size of the silver bromide, the less sensitive the emulsion. Kopriwa (13) did not recommend the combination of phenidon developer and Sakura NR-H2 simply because of its lower sensitivity. Although Hattori et al. (7) reported that development at $6^{\circ} \mathrm{C}$ gave satisfactory results when combining phenidon developer with Sakura NR-H2 ,investigators of the same group (5) also mentioned that the results obtained by the combination of phenidon developer and Sakura NR-H2 were not uniform. On the other hand, the "LIGOP" method introduced by Bouteille (3) made it possible to obtain stable radioautograms. Gold latensification before development was formerly introduced by Salpeter and Bachman (24) and Wisse and Tates (28). In the present study, the application of phenidon development to Sakura NR-H2 was preceded by gold latensification, and stable electron microscopic radioautograms useful for quantitative electron microscopic radioautographic study were obtained. The idea for this developmental method was developed by Bouteille and the present authors independently $(3,16,17,18)$ and the details are somewhat different.

\section{MATERIALS AND METHODS}

\section{(1) Radioisotope labeling}

Dunn and Potter's mastocytoma cells, rabhit bone marrow cells and $\mathrm{HeLa}$ cells were labeled in vitro with Eagle's MEM containing either ${ }^{3} \mathrm{H}$-thymidine or $3 \mathrm{H}$-uridine in a concentration of $100 \mu \mathrm{Ci} / \mathrm{ml}$ for 60 min. Rabbit bone marrow cells were also labeled with Eagle's MEM containing carrier free ${ }^{35} \mathrm{~S}$-sulfuric acid in a concentration of $1 \mathrm{mCi} / \mathrm{ml}$ for $60 \mathrm{~min}$. Mouse cornea was labeled with Eagle's MEM containing ${ }^{3} \mathrm{H}$-proline in a concentration of $100 \mu \mathrm{Ci} / \mathrm{ml}$ for $60 \mathrm{~min}$.

\section{(2) Tissue preparation}

After incubation, these cells and tissues were washed with Hanks' solution twice and prefixed in $2.5 \%$ glutaraldehyde buffered with $0.1 \mathrm{M}$ phosphate buffer ( $\mathrm{pH} 7.2$ ) for $60 \mathrm{~min}$ at $4^{\circ} \mathrm{C}$, washed with the same buffer overnight and postfixed in $1 \%$ osmium tetroxide for $60 \mathrm{~min}$ at $4^{\circ} \mathrm{C}$. HeLa cells incubated with ${ }^{3} \mathrm{H}$-thymidine were centrifuged, collected as a pellet and put on a small piece of aluminium foil, which was plunged into isopentane at $-160^{\circ} \mathrm{C}$, cooled with liquid nitrogen and freeze dried for $24 \mathrm{hr}$ using the freeze drying apparatus model 3-SE of our department (22) and embedded in Epon.

(3) Radioautographic procedure

Ultrathin sections with light gold interference color were cut with an LKB ultrotome and picked up onto collodion coated copper grids. For the ultrathin sectioning of freeze dried HeLa cells, ethylene glycol was poured in the knife trough instead of water to prevent the diffusion of soluble compounds. Sakura NR-H2 nuclear emulsion diluted 8 times with distilled water was coated, using a small wire loop method. In some cases, a simple mass production method for electron microscopic radioautograms with a large wire loop was used (27). In these cases, the dilution ratio was 3 times. Freeze dried HeLa cells were dry mounted according 
to the procedure of Nagata et al. $(19,20,21)$, while other specimens were wet mounted according to conventional procedure. The anionic surfactant, dioctyl sodium sulphosuccinate, which was successfully introduced in the process of dry mounting radioautography $(19,20,21)$ was also used in the wet mounting method. In each case, $0.2 \mathrm{ml}$ of $2 \%$ dioctyl sodium sulphosuccinate was added to $10 \mathrm{ml}$ of diluted emulsion, thus the final concentration of the surfactant was $0.04 \%$.

After a certain period of exposure under low humidity at $4^{\circ} \mathrm{C}$, most grids were dipped in the solution of gold thiocyanate solution by Salpeter and Bachman (24) for 30 to $45 \mathrm{sec}$ at room temperature, briefly rinsed with distilled water and developed for $1 \mathrm{~min}$ at $18^{\circ} \mathrm{C}$ after the recipe of Lettré and Paweletz. (14). This developer consisted of the following chemicals: distilled water $75 \mathrm{ml}$, ascorbic acid $1.5 \mathrm{gm}$, phenidon $0.25 \mathrm{gm}$, potassium bromide $0.6 \mathrm{gm}$, potassium carbonate $1.3 \mathrm{gm}$, sodium sulfite $20 \mathrm{gm}$, potassium thiocyanate $6 \mathrm{gm}$, and finally distilled water was added to make $100 \mathrm{ml}$ of developer. Except for sodium sulfite, the other chemicals dissolved easily in water at ronm temperature. As the dosage of sodium sulfite in this recipe apparently exceeded the saturation dosage, the filtered developer was used each time. Some grids were developed simply with the phenidon developer, omitting the immersion in gold thiocyanate solution. After washing with distilled water, those grids were fixed in sodium thiosulfate for $5 \mathrm{~min}$, soaked up extra water with the filter paper and put in the oven at $37^{\circ} \mathrm{C}$ to dry. Those grids were stained with lead citrate (23) for 2 min and observed under a Hitachi HS-9 or JEOL-100B electron microscope.

\section{RESULTS AND DISCUSSION}

The combination of phenidon developer and domestic nuclear emulsion, Sakura NR-H2, did not yield good results when simply developed with pheniclon developer alone. The development of the grids with the same developer after gold latensification for 30 to $45 \mathrm{sec}$ produced good electron microscopic radioautograms. The size of silver grains ranged from $40 \mathrm{~nm}$ to $100 \mathrm{~nm}$ when developed at $18^{\circ} \mathrm{C}$. As the temperature of the development fell from $18^{\circ} \mathrm{C}$ to $12^{\circ} \mathrm{C}$, more unstable electron microscopic radioautograms were obtained. Some electron micrographs taken from specimens processed through this method are presented. These are Dunn and Potter's mastocytoma cells and rabbit bone marrow cells incorporating ${ }^{3} \mathrm{H}$-thymidine (Figs. 1-3). ${ }^{3} \mathrm{H}$-uridine incorporation by Dunn and Potter's mastocytoma cells and rabbit bone marrow cell are also shown (Figs. 4-6). Rabbit bone marrow cells and mouse cornea cell incorporating carrier free ${ }^{35} \mathrm{~S}$-sulfuric acid and ${ }^{3} \mathrm{H}$-proline, respectively, are presented (Figs. 7, 8). The dry mounted radioautograms of HeLa cells labeled with ${ }^{3} \mathrm{H}$-thymidine and processed through freeze drying are also shown (Figs. 9, 10).

Since successful use of Young and his coworker's phenidon developer in electron microscopic radioautographic studies $(1,2,25,26)$, this developer is now widely used. Almost all previous experiments were performed with the combination of phenidon developer and Ilford L4 emulsion. The average size of silver bromide of Ilford L4 is $0.12 \mu$, while that of Sakura NR-H2 is $0.07 \mu(15)$. Though we have no experience with the combination of Ilford $\mathrm{L} 4$ and phenidon developer, the smaller the silver bormide is, the less sensitive is the efficiency of the development. 


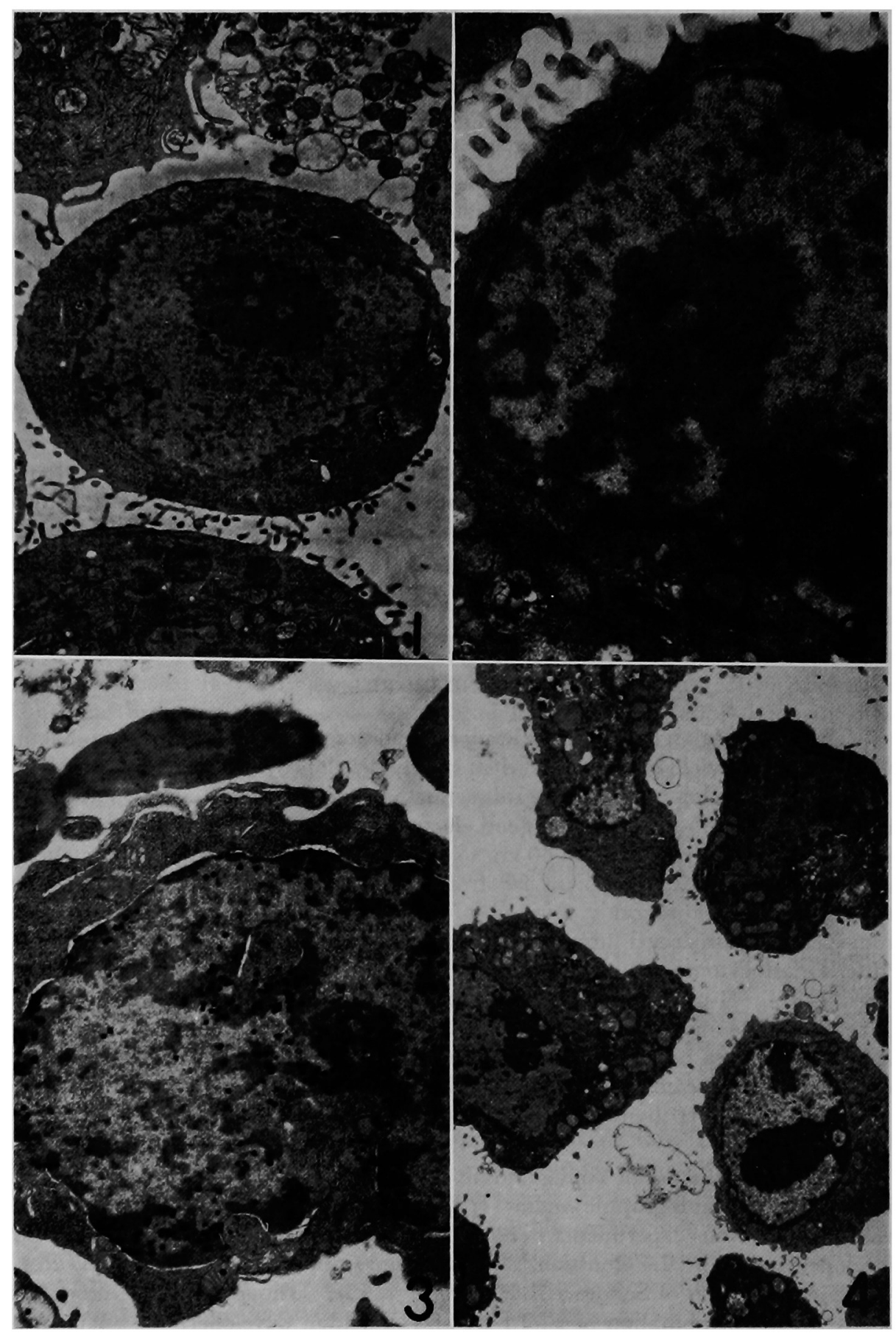




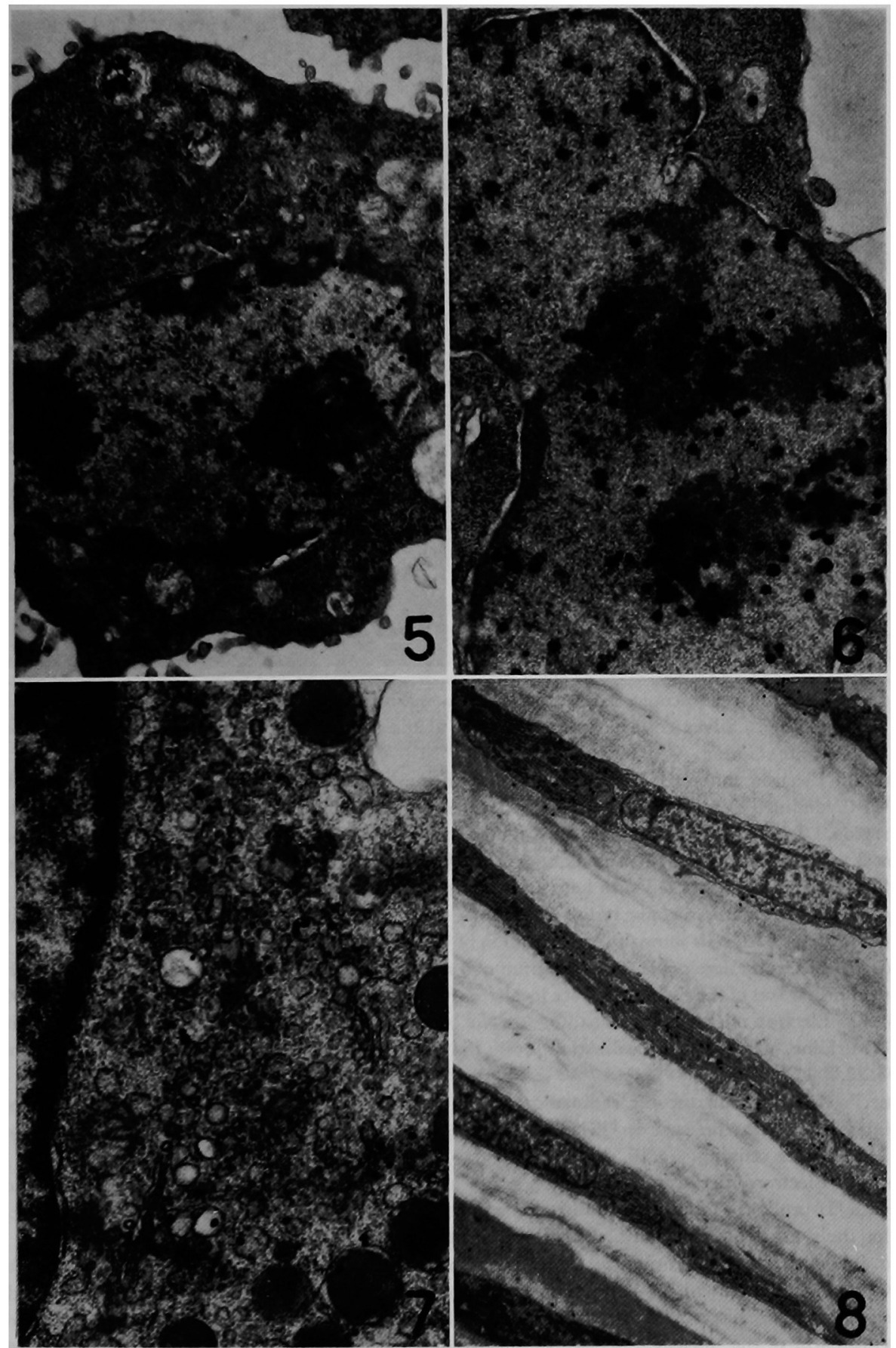




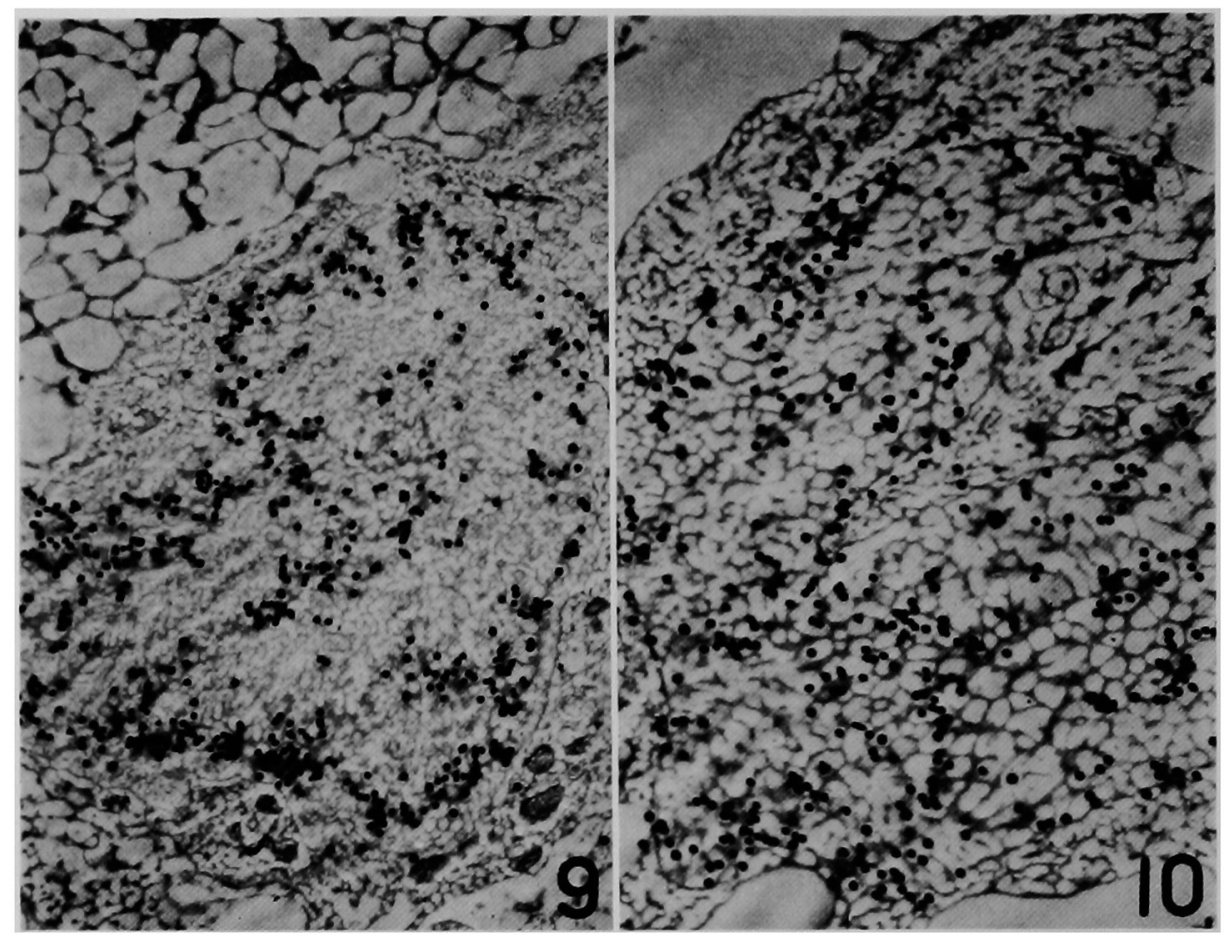

Fig. 1. Electron microscopic radioautogram of a mastocytoma cell after 60 min incubation with ${ }^{3} \mathrm{H}$-thymidine. Silver grains are found mainly at the heterochromatin and perinucleolar region. Lead citrate staining. $\times 8,000$

Fig. 2. Electron microscopic radioautogram of a mastocytoma cell after $60 \mathrm{~min}$ incubation with ${ }^{3} \mathrm{H}$-thymidine. Very fine silver grains are localized at the subnuclear membranous heterochromatin region. Lead citrate staining. $\times 15,000$

Fic. 3. Electron microscopic radioautogram of a basophilic erythroblast labeled with ${ }^{3} \mathrm{H}$-thymidine. Silver grains are associated with heterochromatin. Lead citrate staining. $\quad \times 10,500$

Fig. 4. Electron microscopic radioautogram of mastocytoma cells after 60 min incubation with ${ }^{3} \mathrm{H}$-uridine. All cells show the incorporation of ${ }^{3} \mathrm{H}$-uridine. Lead citrate staining. $\times 4,100$

FIG. 5. Electron microscopic radioautogram of a mastocytoma cell after 60 min incubation with $3 \mathbf{H}$ uridine. Most of the silver grains are localized over two nucleoli. Lead citrate staining. $\times 13,000$

Fig. 6. Electron microscopic radioautogram of a basophilic erythroblast after 60 min incubation with ${ }^{3} \mathrm{H}$-uridine. The same localization over the nucleoli is discernible. Lead citrate staining. $\times 22,000$

Fig. 7. Electron microscopic radioautogram of a rabbit heterophilic promyelocyte after $60 \mathrm{~min}$ incubation with carrier free ${ }^{35} \mathrm{~S}$ sulfuric acid. Silver grains are observed at the Golgi region. Lead citrate staining. $\times 16.500$

FIG. 8. Electron microscopic radioautogram of a 6 day old mouse cornea after 60 min incubation with ${ }^{3} \mathrm{H}$-proline. Fibroblasts of the stroma of the cornea show the incorporation of the amino acid for the synthesis of collagen fibers. Lead citrate staining. $\times 4,500$

Fig. 9 and 10. Dry-mounting electron microscopic radioautograms of freeze-dried HeLa cells after $60 \mathrm{~min}$ incubation with ${ }^{3} \mathrm{H}$-thymidine. Although the cell preservation is not sufficient, most of the silver grains are discernible over the dense area of the nucleus, probably corresponding to the heterochromatin of the nucleus. Several grains are also localized over the cytoplasm. Lead citrate staining. $\quad \times 6,800$ (Fig. 9), $\times 8,000$ (Fig. 10) 
In a very extensive and complicated study, Kopriwa (13) compared four commercially available emulsions using fine grain development. Though the combination of Agfa-Gevaert developer and Sakura NR-H2 was reported to be satisfactory, Kopriwa confessed that the reproducibility of Sakura NR-H2 emulsion was insufficient. According to Kopriwa's report, development in the phenidon-ascorbic acid developer was a less sensitive method for Sakura NR-H2 emulsion. Comparing electron microscopic radioautograms obtained with the combination of AgfaGevaert developer and Sakura NR-H2 and those gained by our method, it is apparent that the latter provides smaller and more uniform and stable silver grains.

Hattori et al. (7) reported a development method with the combination of phenidon developer and Sakura NR-H2. They developed Sakura NR-H2 emulsion at $6^{\circ} \mathrm{C}$, but only one electron microscopic radioautogram was shown in their brief note. The capricious results obtained by the combination of phenidon developer and Sakura NR-H2 were mentioned by the same group of investigators (5), indicating the unstable conditions of this method. Concerning sensitivity of development, phenidon ascorbic acid developer is about twice as sensitive as microdol $\mathrm{X}$ and D-19 $(4,8)$. The gold latensification elon ascorbic acid developer offers the highest sensitivity and phenidon developer ranks second. Silver grains obtained by gold latensification elon ascorbic acid developer, however, are difficult to distinguish and difficult to count $(4,8)$.

On the other hand, the "LIGOP" method (loop-interference gold latensificationphenidon method) developed by Bouteille (3) made it possible to obtain stable electron microscopic radioautorams. We also processed Sakura NR-H2 coated grids in a solution of gold thiocyanate before development $(16,17,18)$. Without gold latensification, stable electron microscopic radioautograms have never been obtained with the combination of phenidon developer and Sakura NR-H2. In the course of this experiment, the anionic surfactant, dioctyl sodium sulphosuccinate, introduced by Nagata et al. $(19,20,21)$ for dry mounting radioautography to prevent the emulsion film from bursting, was employed in wet-mounting procedure. Applying this chemical to wet mounting radioautograph, the authors succeeded not only in preventing the burst of emulsion, but also in obtaining uniform spreading of the emulsion films on the wire loop. For quantitative electron microscopic radioautography, this procedure should be very effective.

\section{ACKNOWLEDGMENT}

The authors are grateful to Prof. A. Ichikawa, Department of Anatomy, Yokohama City University School of Medicine, and Associate Prof. K. Hirosawa, Department of Fine Morphology, Institute of Medical Science, University of Tokyo for their valuable advice during the course of this experiment

\section{REFERENCES}

1. Berg, N. B. and Young, R. W.: Sulfate metabolism in pancreatic acinar cells. J. Cell Biol. $50 ; 469,1971$.

2. Bok, D., Basinger, S. F. and Hall, M. O.: Autoradiographic and radiobiochemical studies on the incorporation of $\left[{ }^{6-}{ }^{3} \mathrm{H}\right]$ glucosamine into frog rhodopsin. Exp. Eye Res. 18; 225, 1974. 
3. Bouteille, M.: The "LIGOP" method for routine ultrastructural autoradiography: a combination of single grid coating, gold latensification and phenidon development. J. Microsc. Biol. Cell. 27; 121, 1976.

4. Bouteille, M., Fakan, S. and Burglen, M-J.: Efficiency, resolution, grain size and grain shape in routine electron microscope autoradiography. J. Microsc. Biol. Cell. 27; 171, 1976.

5. Fujita, S. and Kitamura, T.: Autoradiography: In New Histochemistry, (In Japanese). ed. by K. Ogawa, T. Takeuchi and T, Mori, Asakura Shoten., Tokyo, 1975, p. 60.

6. Hama, K. and Hirosawa, K.: High voltage electron microscopy; a study of autoradiography. J. Elect. Microsc. 26; 187, 1977.

7. Hattori, H., Kitamura, T. and Fujita, S.: Low temperature development of electron microscopic autoradiography. (In Japanese). Igaku No Ayumi 85; 237, 1973.

8. Heijnen, H. and Geuze, H.: Phenidone-ascorbic acid development in electron microscopic autoradiography. Histochemistry 54; 39, 1977.

9. Hirosawa, K. and Yamada, E.: The localization of the vitamin A in the mouse liver as revealed by electron microscope radioautography. J. Elect. Microsc. 22; 337, 1973.

10. Hirosawa, K. and Yamada, E.: Localization of vitamin A in the small intestine of mouse: an electron microscope radioautographic study. Cell Tiss. Res. 177; 57, 1977.

11. Ichikawa, A. and Ichikawa, M.: Structural analysis of the secretory process of the salivary gland. (In Japanese). Denshikenbikyo 13; 106, 1978.

12. Ishiko, S.: An EM radioautographic study of the DNA replication sites in mammalian cells. Nihon Idai Zasshi 44; 162, 1977.

13. Kopriwa, B. M.: A comparison of various procedures for fine grain development in electron microscopic radioautography. Histochemistry 44; 201, 197.5.

14. Lettré, H. and Paweletz, N.: Probleme der elektronenmikroskopischen Autoradiographie. Naturwissenschaften 53;268, 1970.

15. Mizuhira, V. and Uchida, K.: Autoradiography and histo-cytochemistry. (In Japanese). Kagaku to Seibutsu 5; 54, 1967.

16. Murata, F., Momose, Y. and Nagata, T.: Ultrastructural comparison of mast cells and mastocytoma cells in the mouse. J. Elect. Microsc. 25; 197, 1976.

17. Murata, F., Momose, Y., Yoshida, K. and Nagata, T.: Radioautographic study of the mucosubstances in the rabbit bone marrow cells. (In Japanese). Acta Anat. Nippon .52; 44, 1977.

18. Murata, F., Yoshida, K. Ohno, S. and Nagata, T.: Mucosubstances of the granulocytes studied by means of electron microscopic radioautography and $\mathrm{x}$-ray microanalysis. Proc. 9th Int. Cong. Electron Microscopy 2; 454, 1978.

19. Nagata, T.: The techniques and the application of radioautography. (In Japanese). Ed. by T. Matsuzawa, Asakura Shoten, Tokyo, 1969, p 82.

20. Nagata, T. and Nawa, T.: A modification of dry-mounting techniques for radioautography of water soluble compounds. Histochemie 7; 370, 1958.

21. Nagata, T., Nawa, T. and Yokota, S.: A new technique for electron microscopic dry-mounting radioautography of soluble compound. Histochemie 18; 241, 1969.

22. Nawa, T., Nagata, T., Yokota, S., Murata, F. and Omochi, S.: Two new models of freezedrying apparatus for tissues. Med. J. Shinshu L'niv. 14; 1, 1968.

23. Reynolds, E. S.: The use of lead citrate at high $\mathrm{pH}$ as an electron-opaque stains in electron microscopy. J. Cell Biol. 17; 208, 1963.

24. Salpeter, M. M. and Bachman, L.: Autoradiography with the electron microscope: a procedure for improving resolution, sensitivity, and contrast. J. Cell Biol. 22; 469, 1964.

25. Young, R. W. and Bok, D.: Participation of the retinal pigment epithelium in the rod outer segment renewal process. J. Cell Biol. 42; 392, 1969.

26. Young, R. W: : The role of the Golgi complex in sulfate metabolism. J. Cell Biol. 57; 175, 1973.

27. Yoshida, K., Murata, F., Ohno, S. and Nagata, T.: A modified wire-loop method for quantitative electron microscopic radioautography. Histochemistry 57; 93, 1978.

28. Wisse, E. and Tates, A. D.: A gold latensification. Elon ascorbic acid developer for Ilford L4 emulsion. Proc. 4th Eur. Reg. Conf. Electron Microscopy 465, 1968. 